\title{
LC Headings from August-November 2018 Lists
}

\section{Compiled by Ann Heinrichs}

The new headings listed here reflect the most recent information available at the time of publication. Items in this list were selected from the 2018 list numbers 08 (August 17), 09 (September 14), 10 (October 12), and 11 (November 19).

\section{SUBJECT HEADINGS}

130 Bible--Transgender interpretations [sp2018001298]

450 UF Transgender interpretations of the Bible

530 BT Bible--Criticism, interpretation, etc.

680 Here are entered works on Biblical interpretation from a transgender viewpoint, emphasizing such matters as transsexual identities.

150 Bible stories, Fijian [May Subd Geog] [sp2018002376]

450 UF Fijian Bible stories

150 Bible stories, Tahitian [May Subd Geog] [sp2018002375]

450 UF Tahitian Bible stories

150 Bishops--Dwellings--Romania [sp2018002078]

150 Cell culture--Religious aspects [sp2018000662]

150 Cell culture--Religious aspects--Islam [sp2018000663]

150 Comic books, strips, etc.--Religious aspects--Catholic Church [sp2018002039]

150 Data curation [sp2015001855]

450 UF Data libraries--Collection management DELETE FIELD

150 Data libraries CHANGE HEADING

150 Data centers [May Subd Geog] [sp 85035856]

450 UF Data libraries [Former heading]

450 UF Datacenters

550 BT Computer service industry

680 Here are entered works on facilities that organize, process, store, and disseminate large amounts of data.

Ann Heinrichs is Metadata/Cataloging Librarian at Catholic Theological Union. 
150 Data sets [May Subd Geog] [sp2018002256]

450 UF Datasets

450 UF Raw data sets

550 BT Computer files

550 BT Electronic information resources

680 Here are entered works on collections of discrete items of related data that can be accessed individually, in combination, or as a whole. Works on collections of resources in digital formats are entered under Digital libraries.

150 Digital libraries [May Subd Geog] [sp 95008857 ]

680 Here are entered works on collections of resources in digital formats. Works on collections of discrete items of related data that can be accessed individually, in combination, or as a whole are entered under Data sets. ADD FIELD

150 Faerie Faith (Wiccan sect) [May Subd Geog] [sp2017004664]

550 BT Wiccan sects

680 Here are entered works on the Dianic tradition that does not have a pantheon, and instead emphasizes the feminine in humanity, in nature, and in god, and whose members believe in energies that are correlated to the thirteen lunar months of the Celtic lunar tree calendar. Works on the Wiccan sect in which the primary myths are drawn heavily from the myths of ancient Celtic gods and goddesses, and whose primary deity is Dana, the Mother Goddess, are entered under Faery-Faith (Wiccan sect). Works on the ecstatic cult whose primary deity is the Star Goddess and whose gods are both male and female in one are entered under Feri (Wiccan sect).

681 Notes under Feri (Wiccan sect); Faery-Faith (Wiccan sect)

150 Faery-Faith (Wiccan sect) [May Subd Geog] [sp2017004904]

450 UF Irish American Faery-Faith (Wiccan sect) DELETE FIELD

680 Here are entered works on the Celtic reconstructionist sect Faery Faith, founded by Kisma Stephanich. Worship is according to the Ogham associated with each lunar cycle and pedagogical pathworking to develop bardic skills. As a bardic tradition, it has as its key text the Lebor Gabála Érenn. Works on the Dianic sect Faerie Faith, founded by Epona in Atlanta, Georgia, are entered under Faerie Faith (Wiccan sect). Works on the pre-Gardnerian Wiccan sect Feri, founded by Victor and Cora Anderson, are entered under Feri (Wiccan sect) DELETE FIELD

680 Here are entered works on the Wiccan sect in which the primary myths are drawn heavily from the myths of ancient Celtic gods and goddesses, and whose primary deity is Dana, the Mother Goddess. Works on the ecstatic cult whose primary deity is the Star Goddess and whose gods are both male and female in one are entered under Feri (Wiccan sect). Works on the Dianic tradition that does not have a pantheon, and instead emphasizes the feminine in humanity, in nature, and in god, and whose members believe in energies that are correlated to the thirteen lunar months of the Celtic lunar tree calendar, are entered under Faerie Faith (Wiccan sect). ADD FIELD 
$150 \quad$ Fantasy fiction--Religious aspects [sp2018001608]

150 Fantasy fiction--Religious aspects--Catholic Church [sp2018001609]

150 Feri (Wiccan sect) [May Subd Geog] [sp2017004663]

450 UF Anderson Feri (Wiccan sect)

450 UF Faerie (Wiccan sect)

450 UF Faery (Wiccan sect)

450 UF Fairy (Wiccan sect)

450 UF Feri Faith (Wiccan sect)

450 UF Phary (Wiccan sect)

450 UF Pictish (Wiccan sect)

450 UF Vicia (Wiccan sect)

550 BT Wiccan sects

680 Here are entered works on the ecstatic cult whose primary deity is the Star Goddess and whose gods are both male and female in one. Works on the Wiccan sect in which the primary myths are drawn heavily from the myths of ancient Celtic gods and goddesses, and whose primary deity is Dana, the Mother Goddess, are entered under Faery-Faith (Wiccan sect). Works on the Dianic tradition that does not have a pantheon, and instead emphasizes the feminine inhumanity, in nature, and in god, and whose members believe in energies that are correlated to the thirteen lunar months of the Celtic lunar tree calendar, are entered under Faerie Faith (Wiccan sect).

681 Notes under Faerie Faith (Wiccan sect); Faery-Faith (Wiccan sect)

150 Gañgā (Hindu deity) CANCEL HEADING [sp 89000160 ]

682 This authority record has been deleted because the subject heading is covered by an identical name heading (DLC)n 2018241436

150 Gurneyites [May Subd Geog] [sp2018002296]

450 UF Evangelical Friends (Gurneyites)

550 BT Society of Friends

150 Indigenous peoples--Missions [May Subd Geog] [sp2018002653]

150 Industrial management--Religious aspects [sp2018002266]

150 Industrial management--Religious aspects--Christianity [sp2018002264]

150 Invisibility--Religious aspects [sp2018002174]

150 Jewish hymns [May Subd Geog] ADD GEOG [sp 85070285 ]

450 UF Hymns, Jewish DELETE FIELD

550 BT Hymns ADD FIELD 
151 Jordan--In the Bible [sp2018002183]

150 Juquila, Nuestra Señora de [sp2018002316]

450 UF Nuestra Señora de Juquila

450 UF Nuestra Señora de Xuquila

450 UF Nuestra Señora Inmaculada de Juquila

450 UF Our Lady of Juquila

450 UF Virgin of Juquila

450 UF Xuquila, Nuestra Señora de

500 BT Mary, Blessed Virgin, Saint--Devotion to--Mexico

150 Luciferians (Christian heresy) [May Subd Geog] [sp2018001735]

053 BT1397

550 BT Christian heresies--History--Early church, ca. 30-600

150 Motivation in Islamic education [May Subd Geog] [sp2018001971]

053 LC905.M68

550 BT Islamic education

150 Muslim politicians [May Subd Geog] [sp2018001911]

450 UF Islamic politicians

550 BT Politicians

150 Older Neopagans [May Subd Geog] [sp2018001836]

550 BT Neopagans

550 BT Older people

150 Paganism in motion pictures [Not Subd Geog] [sp2018001581]

550 BT Motion pictures

150 Pageants--Religious aspects [sp2018001505]

150 Pageants--Religious aspects--Mormon Church [sp2018001506]

110 Parsonage (New York, N.Y. : Arthur Kill Road) [sp2017005181]

550 BT Parsonages--New York (State)

150 Parsonages--New York (State) [sp2018001405]

150 Parturition--Religious aspects [sp2018002449]

150 Parturition--Religious aspects--Neopaganism [sp2018002161] 
150 Pentecostal men [May Subd Geog] [sp2018001762]

550 BT Christian men

150 Quaker church buildings--England [sp2018002445]

150 Rachmastrivka Hasidim [May Subd Geog] [sp2018001353]

450 UF Rotmistrovka Hasidim

550 BT Hasidism

150 Shamans in art [Not Subd Geog] [sp2018001816]

150 Superheroes--Religious aspects--Catholic Church [sp2018002040]

150 Tissue culture--Religious aspects [sp2018000664]

150 Tissue culture--Religious aspects--Islam [sp2018000665]

150 Trappist beers [May Subd Geog] [sp2018001829]

550 BT Beer

150 Vishnu (Hindu deity) CANCEL HEADING [sp 85143862 ]

682 This authority record has been deleted because the subject heading is covered by an identical name heading (DLC)n 2018242971

150 Vishnu (Hindu deity) in literature CANCEL HEADING [sp 94008903]

682 This authority record has been deleted because the heading is replaced by the heading Vishnu (Hindu deity)--In literature, a heading for which a subject authority is not made because it uses a free-floating subdivision.

150 Visibility--Religious aspects [sp2018002173]

150 Zine libraries [May Subd Geog] [sp2018001741]

550 BT Special libraries

150 Zombies--Religious aspects [sp2018002037]

150 Zombies--Religious aspects--Buddhism [sp2018002038] 


\section{GENRE/FORM TERMS}

155 Bar mitzvah sermons [gp2018026106]

455 UF Bar mitsỵah sermons

455 UF Bar mitzva sermons

455 UF Bar mitzwa sermons

455 UF Barmitzvah sermons

555 BT Occasional sermons

155 Christmas pantomimes [gp2018026113]

455 UF Mime plays (Christmas pantomimes)

455 UF Pantomime plays (Christmas pantomimes)

455 UF Pantos (Christmas pantomimes)

555 BT Christmas plays

680 Christmas entertainments for children that are embellished fairy tales, and feature a male playing the principal female role and a female playing the principal male role.

155 Christmas sermons [gp2015026084]

555 BT Sermons DELETE FIELD

555 BT Occasional sermons ADD FIELD

155 Easter sermons [gp2018026105]

555 BT Occasional sermons

155 Funeral sermons [gp2015026085]

555 BT Sermons DELETE FIELD

555 BT Occasional sermons ADD FIELD

155 Lenten sermons [gp2018026104]

455 UF Lent sermons

555 BT Occasional sermons

155 Occasional sermons [gp2018026107]

555 BT Sermons

680 Sermons written for particular occasions.

155 Thanksgiving Day sermons [gp2015026086]

555 BT Sermons DELETE FIELD

555 BT Occasional sermons ADD FIELD

155 Wedding sermons [gp2018026108]

455 UF Nuptial sermons

555 BT Occasional sermons 